\title{
Reinstating the Roles of Maqasid al-Shari'ah
}

\author{
Ahmad Badri Abdullah*
}

In recent decades, due to different factors, awareness of the critical importance of maqasid al-shari'ah as the foundation of the Islamic legal system has been on a rising trend. It has become a timely topic in different spheres, especially Islamic studies and research. Numerous academic works in contemporary Islamic scholarship have used maqasid al-shari'ah as a theoretical basis. They range from university dissertations to academic journals, to books, to policy papers. In some Muslim countries, like Malaysia, maqasid al-shari'ah has become a national agenda with the launch of the Shari'ah Index, a governance metric that uses maqasid principles to gauge the country's performance from the Islamic outlook.

Nonetheless, there is an Achilles' heel to all this positive development, i.e. a perplexity concerning the roles of maqasid al-shari'ah and how it should actually function to offer guidance in different spheres of life. This, among other things, is due to the fact that the majority of research on maqasid merely draws attention to the five essentials (daruriyat al-khams), disregarding other important dimensions of the discourse. Researchers tend to exercise intellectual gymnastics, trying to justify their findings as serving the preservation of the five elements of religion, life, reason, progeny and wealth, as if they are the only maqasid aspects that demand attention. Moreover, there is also a claim that focusing on maqasid signifies a loose commitment to textual sources (nusus) and even, in some cases, an antithetical approach to their rulings. Therefore, for those who believe so, maqasid al-shari'ah is reduced to merely functioning as the underlying wisdom (hikmah) of textual rulings, having no bearing whatsoever in any legal postulation.

Therefore, this brief article would like to shed some light on the roles and objectives of maqasid al-shari'ah as a discourse and a number of functions that it aims to fulfill. The main part of this article is consequently on how maqasid alshari'ah would deal with Islamic textual sources and what is the logic that it has to offer in order to function in spheres beyond the Islamic legal system.

One of the main objectives of maqasid as a discourse is its role as guide in understanding the Qur'an and hadith texts. According to the maqasid discourse, the Qur'anic text is an integrated whole that demands a holistic approach for its analysis. It is worth noting that the underpinning logic that the Qur'an promotes is teleological. Therefore, classical scholars and their contemporaries have never failed to outline a list of Quranic objectives. They are a set of objectives that 
govern the correct understanding of any particular verse, chapter and the entire text as a whole.

As for hadith, maqasid demands that an analysis of any hadith text should incorporate awareness of the different roles assumed by the Prophet in different settings. This is due to the fact that, as argued by Ibn Ashur and al-Qarafi, the Prophet performed different roles in his lifetime, making each of them key to determining the intentions behind his words and instructions to his Companions. Furthermore, another key to maqasid-based hadith analysis is the understanding of context. Disregarding the socio-economic-political background of some hadiths will lead to distortions of actual aims or purposes.

Another important role of maqasid is as the governing theoretical foundation for legal reasoning. Al-Shatibi, in delineating the four prerequisites of ijtihad, firmly contended that jurists are obliged to observe maqasid aspects in all of their rulings. In the same vein, 'Allal al-Fasi asserted that maqasid al-shari'ah has never been a secondary reference in the historical development of figh or deemed as an external source for such a process; rather, scholars have directly or indirectly viewed it as an embedded ijtihad component. At best, as argued by Ibn Ashur, maqasid and textual rulings are closely intertwined in a feedback loop equation in which both are mutually dependent and in need of one another. None of them could independently function without the other, as correctly put by al-Fasi:

In Shari'ah, rulings are based on the maqasid, while the maqasid are in turn based on rulings.

Ahmad al-Raysuni outlines at least ten measures of a maqasid-based approach in the ijtihad process. However, due to space limitation this article will only touch briefly on several important measures that deserve utmost attention. Firstly, maqasid discourse necessitates investigation into the actual meaning of any textual source, ascertaining its underlying objectives, either from its direct literal wording or anything beyond the letters. Investigating wisdom (hikmah) and benefits (maslahah) behind any ruling is also indispensable in the process of ijtihad. It is important for jurists to discriminate between the unintended objectives and the intended objectives of any ruling. They need as well to differentiate between the intrinsic and external objectives of any rulings and try their best to preserve the general objectives (maqasid al- 'am) in each and every application of a specific ruling. In the lens of maqasid, rulings are not uniform, but function in hierarchical levels, depending on the degree of benefits they aim to achieve, or the degree of harm they aim to prevent.

Moreover, according to al-Raysuni, jurists are obliged to preserve the maqasid aspects in the process of analogous reasoning (qiyas). Just as a literalistic approach to textual analysis will result in inaccurate decisions, a conservative approach to 
qiyas may also bring about similar consequences. To overcome this problem, it is proposed that, in legal reasoning, jurists should prioritise the universal and general principles of Shari'ah (kulliyah al-Shar'iyyah) over resorting to qiyas in deciding new issues. This is, in fact, a widely accepted practice across jurisprudential schools (madhahib) and held by the majority of their scholars. Nonetheless, this does not render qiyas invalid; rather, it highlights the situations where a strict adherence to the mechanism is counterproductive.

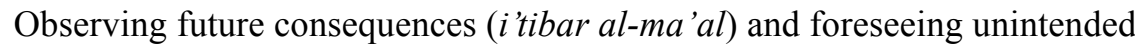
results of a decision is part and parcel of the maqasid-based approach in legal reasoning. The benefits or harm accruing from any particular action or transaction do not merely surface during its initial phase but also, and more importantly, in its consequences or results. An action which initially fosters benefit in the present may nevertheless subsequently result in harm in the future, or vice versa. Therefore, safeguarding the maqasid aspect in decision-making would mean due observance of the future consequences and results of a ruling, and putting them into full consideration whenever they seem to be of high probability. In sum, a credible legal reasoning would involve both present and future consideration of an issue.

It could be argued then, that maqasid-based legal reasoning designates a measure to strike a balance between adhering to textual demands and pragmatic attainment of benefits and welfare.

Although maqasid al-shari'ah has yet to develop into a full-fledged and independent discipline, it possesses an intrinsic logical system that enables it to function beyond Islamic law and jurisprudence. This logical framework, which maqasid al-shari' ah aims to promulgate, is in conformity with systems thinking. In other words, it is in fact a systems-based approach. Firstly, it promotes goaloriented reasoning and purpose-based analysis as its central methodology, a neglected aspect of modern natural and social sciences. Secondly, it advances multidimensional analysis which connotes the ability to identify complementary relations in opposing tendencies. It designates as well a non-zero-sum game whereby a loss for one side does not necessarily mean a gain for the other but both of the opposing tendencies might increase or decrease simultaneously. Thirdly, maqasid presupposes the notion of the interrelation of things in the form of nonlinear feedback-loops, an approach that is imperative in addressing complexities in current socio-economic-political realities. Finally, maqasid al-shari'ah as a discourse highlights that forecasting the future effects of an action or intervention is highly imperative in the process of reasoning or planning.

Through this logical scheme, maqasid al-shari'ah is able to extend its roles beyond the field of Islamic jurisprudence, offering holistic guidance for public policies, organisational management and country development. Those are the 
aspects that should have captured researcher's attentions and focus, for them to propose measures and mechanisms by which the functional roles of maqasid could become a reality in different life segments.

\section{Notes}

* Ahmad Badri Abdullah is a Research Fellow at the International Institute of Advanced Islamic Studies (IAIS) Malaysia. He can be contacted at badri@iais. org.my. 